\title{
High Quality Liquid Sukūk: Relevance, Practice, and Empirical Research in the Context of Rising Global Interest Rates
}

\author{
Abdullah Karatas ${ }^{1,2}$ \\ ${ }^{1}$ Islamic Development Bank, Jeddah, Kingdom of Saudi Arabia \\ ${ }^{2}$ INCEIF, Kuala Lumpur, Malaysia \\ Correspondence: Abdullah Karatas, Islamic Development Bank, Jeddah, Kingdom of Saudi Arabia. \\ Received: December 6, 2016 \\ Accepted: January 20, 2017 \\ Available online: February 6, 2017 \\ doi:10.11114/aef.v4i2.2046 \\ URL: http://dx.doi.org/10.11114/aef.v4i2.2046
}

\begin{abstract}
Liquidity management has always been a major issue in Islamic banking. In the early years of the industry, a major problem was a general tendency toward excess liquidity. In the future, the main issue in the context of depressed oil prices, a rising global interest-rate environment, and a tightened regulatory landscape under Basel III is likely to be a relative scarcity of high quality liquid assets (HQLA), or high quality liquid sukūk (Note 1). The incoming U.S. Treasury secretary Steven Mnuchin has already indicated that the Trump administration's plans could rapidly turbocharge the U.S. economy, thereby altering the prevailing low-interest rate dynamic at the U.S. Federal Reserve (“U.S. Fed"), leading many to anticipate higher interest rates (Wigglesworth \& Moore, 2016).

Among the available liquidity management instruments in Islamic banking, only sukūk of a particular type meet the requirements of HQLA (in principle) as defined by the Basel Committee and adapted for Islamic finance by the IFSB (Islamic Financial Services Board). Candidates for HQLA are only international sukūk, i.e. sukūk that are issued in an international currency, listed, and traded not only locally but also internationally. Sovereigns and international institutions such as the IDB have issued almost all sukūk of this caliber. In this paper, we will make empirically informed qualitative projections on the outlook for HQL (high quality liquid) sukūk in the context of a rising global interest-rate environment.
\end{abstract}

Keywords: sukūk, bonds, liquidity, high quality liquid assets, interest rates, liquid assets buffer

\section{Introduction}

Islamic finance has developed a range of Sharī' ah compliant (Note 2) liquidity management tools, comprising mainly of commodity murābahah placements (Note 3), short-term trade finance investments, and sukūk (Note 1). Islamic finance as an industry has increased in size and systemic relevance in a number of countries, in particular in Malaysia and the GCC (IFSB, 2016), and chances are that plans for the establishment of a globally active Islamic megabank will be realized in the not too distant future. Such a megabank might be or come close to a G-SIB (global systemically important bank) for Islamic finance. It could be the result of a merger of pre-existing banks or it could be a completely new private or government-linked venture e.g. a multilateral development bank or MDB (Karatas, 2016).

For any large and internationally operating Islamic flagship bank, it is safe to assume that it will adhere to Basel III standards, which require, among others, a buffer of HQLA that is proportionate to the size and risk profile of the bank. While this buffer requirement would not strictly apply to an MDB, it would be an explicit obligation for a private megabank established in a country that applies Basel III rules. However, an MDB would be well advised to adhere to Basel III standards in order to secure top ratings from the established credit rating agencies whose methodologies include Basel III equivalent requirements. An MDB would partially achieve this goal by maintaining an adequate LAB (liquid assets buffer) portfolio. The MDB can lower its cost of funding by securing top ratings, and thereby more effectively conduct its operations (Karatas, 2016).

In previous papers, we have addressed from different angles the identification of relevant HQL sukük and the analysis of empirical market practices and market behaviors. In this paper, we will bring all of the previous analyses together to make informed qualitative projections for HQL sukūk in the context of a rising global interest-rate environment.

\subsection{Sukūk Issuances, Pricing and Trading in Interlinked Markets}

In the aftermath of the U.S. election victory of President Donald J. Trump, there is an increased likelihood that the 
world will enter a period of rising global interest rates. President Trump's aim to stimulate growth in the U.S. economy through increased fiscal expenditures would mark the end of more than a decade of declining interest rates. In fact, since the November 8, 2016, election results became public, there has been a veritable rout in the sovereign bond markets with bond yields of most developed economies climbing steeply. On Thursday December 1, 2016, the benchmark yield of the ten-year maturity U.S. Treasury bond climbed to $2.49 \%$, its highest level since June 2015 (Wigglesworth \& Moore, 2016). Given the strong interlinkages between the sukūk and the conventional bond markets as observed empirically based on yield curve parallelism, the rising global interest rate environment will undoubtedly carry through and have an impact on the sukūk markets, in the form of issuances, pricing and trading (Nienhaus \& Karatas, 2016).

We have addressed from different angles the identification of relevant sukūk and the analysis of empirical market practices and market behaviors in previous papers. Nevertheless, we believe that it is important to bring all of the previous analyses together to make informed and empirically sound qualitative projections for HQL sukūk, and thereby a megabank MDB's LAB portfolio, in the context of a rising global interest-rate environment. This is especially important given the relative absence of empirical research on sukūk (Zulkhibri, 2015).

In addition, much of the scholarly research on Islamic finance is mainly confined to empirical verification of its performance on the argument that Islamic finance is distinct from conventional finance (Ibrahim, 2015; Ariff \& Safari, 2012). This paper, by combining the analyses across our previous studies, should enrich the empirical finance academic literature dealing with HQL sukūk.

\subsection{Identification of Sukūk Issuances That Have HQLA Features}

In a previous paper, while screening and sorting all outstanding sukūk (as of February 1, 2016), we came across some classification issues in the Bloomberg database which is widely used among researchers. There were 2,135 different sukūk issuances in the market for a total combined notional exposure of USD 332 billion according to Bloomberg data. While $54.5 \%$ of the total sukūk volumes were denominated in Malaysian Ringgit, the remaining sukūk were primarily issued in the currencies of Indonesia, Qatar, Saudi Arabia and Turkey. Issuances by multilateral institutions (such as the IDB) are attributed to the country of their headquarters, whereas it would be more accurate to classify them as "supranational." In terms of the issuance currency, MDBs predominantly issue sukūk in SDR currencies, which comprise the special drawing rights of the IMF. The SDR currency basket includes the U.S. dollar, the Euro, English Sterling, the Japanese Yen, and the Chinese renminbi (Karatas, 2016).

Market players and actors of different characters are sometimes aggregated in the same group - for example, the Government sector category also includes supranational issuers, government related entities, and government agencies that we thought appropriate to separate in the analysis for portfolio construction purposes. For many research topics, it is more appropriate to separate or re-cluster the sub-categories (Karatas, 2016). Fortunately, this was possible with reasonable efforts for our topics, but the general finding is that one should not blindly use pre-fabricated aggregates. Differences and heterogeneities within published aggregates cannot be seen from the names of the aggregates, and conclusions based on these names could be somewhat biased or distorted (Karatas, 2016).

\subsection{Pricing and Trading}

Having identified sukūk with HQLA qualities, the question of the pricing and trading of such sukūk comes up. While data on sukūk pricing in the primary market and on sukūk yields in the secondary markets are readily available, reliable information on changes in holding patterns after issuance (i.e. as a result of secondary market trading activities) and trading volumes are widely lacking. The reason for this lack of relative transparency is that most of the trading is done through non-reported OTC (over-the-counter) transactions.

In the primary markets, potential investors "pad" their expressed interest in a bond or sukūk issuance in order to secure their target allocation; therefore, the expressed demand for a given issuance in the form of the order book's size does not always reflect the actual demand. The real, actual demand for a bond or sukūk issuance, which is the ultimate arbiter of the pricing at the time of issuance, ceteris paribus, is determined by the strength of the "buy-side" demand for a given bond or sukūk issuance (Nienhaus \& Karatas, 2015).

\subsection{Literature Review}

A market maker is a trader who typically sits on a trading desk housed within one of the global investment banks. A market-making desk falls under the "sell-side" in the finance world where there is a divide between the buy-side or end-user investors, and the sell-side. The sell-side, in the form of brokers, primarily plays an intermediary sales role. Buying and selling of securities by the buy-side is what determines the securities' prices (Nienhaus \& Karatas, 2015). This simple fact may appear to contradict a lot of the academic literature on the topic that ascribes other pricing variables and methodologies to determine the price (and yield spread) of a sukūk instrument (Naifar \& Mseddi, 2013). Nevertheless, this truism is similarly the case for academic literature that deals with conventional bond pricing 
methodologies. Academic theory often ascribes pricing methodologies that appear to complicate or contradict the market reality: simple supply and demand determines the prices of traded financial instruments, including conventional bonds.

Islamic investors prefer OTC transactions and thereby do not register their buy-and-sell transactions on Bloomberg. Consequently, we can plausibly assume that Islamic investors comprise a large proportion of non-recorded sukūk investors. Or else the proportion of Islamic investors present in most outstanding sukūk issuances would be very low (i.e. under $1 \%$ of the total holdings), which is demonstrated to not be the case based on our empirical findings. Additionally, the data on conventional bonds confirms a higher level of Bloomberg database registration of conventional investors (Nienhaus \& Karatas, 2016).

Given reporting standards in the United States, where a significant proportion of USD-denominated bond investors are based, the higher level of Bloomberg database registration of conventional investors is not surprising. Since the vast majority of sukūk investors are domiciled outside the United States, it naturally explains the lower proportion of Bloomberg database registration and the fact that they are under-reported. The vast majority of USD-denominated sukūk are registered as Regulation S securities (Note 4). The reporting requirements in the United States mandate the reporting of OTC fixed income transactions in the secondary markets per TRACE (Trade Reporting and Compliance Engine), developed by FINRA (Financial Industry Regulatory Authority) of the United States (Nienhaus \& Karatas, 2016).

The most striking finding from the holding pattern analysis is that conventional investors composed a relatively minor portion of every sukūk issuance; non-Islamic investors held less than $10 \%$ of the total outstanding sukūk in seven of the eight analyzed issuances (Nienhaus \& Karatas, 2016). Hence, it is safe to say that while conventional market actors are active in the markets as market makers, the absolute size of conventional investors' holdings and the level of their trading volumes are not significant enough to singularly determine sukūk prices in the primary markets. For price changes in the secondary markets, the sway of non-Islamic brokers is debatable: since most Islamic investors maintain their sukūk until maturity, conventional brokers conduct a significant portion of selling activity, which would have an impact on prices.

Consequently, Islamic investors remain the primary deciders of the market equilibrium price in the primary markets through their sukūk buy or sell actions. Those actions, however, rarely occur independent of considerations regarding the broader financial markets as the analysis of the pair-wise yield curves demonstrates (Nienhaus \& Karatas, 2016), even if other studies suggest a more discrete relationship based on significant differences between yields for sukūk and conventional bonds (Ariff \& Safari, 2012). Other channels for the diffusion of impulses from conventional bond markets to sukūk include the use of conventional measurement benchmarks in Islamic finance as well as strong interdependencies that manifest themselves through the equity markets (Maghyereh \& Awartani, 2016).

It is important to point out that for the purposes of our study in our earlier paper (Nienhaus \& Karatas, 2016), we compiled data on market transactions in particular yield curves, holding patterns, and indications of significant conventional investor participation in large actively traded sovereign sukūk denominated in international currencies. Our analysis was limited to this category of sukūk, and we concentrated on sukūk markets with depth, namely Turkey, Indonesia, Hong Kong, and Malaysia (Nienhaus \& Karatas, 2016). There have been other analyses focusing on relatively less liquid sukūk markets such as the GCC, and often focusing on sukūk (i.e. local currency-denominated) that witness a lower degree of participation by conventional investors, which have found lower levels of interlinkages between the sukūk and conventional bond markets (Naifar \& Hammoudeh, 2016). Additionally, other papers have focused on only one jurisdiction, namely on securities within the Malaysian context, and on local-currency issuances with lower levels of conventional investor participation (Ariff \& Safari, 2012).

Our selection criteria for the pair-wise sukūk and conventional bond analysis, as detailed in section 2.1, was more stringent, however, to ensure accurate comparisons as much as possible. In our earlier paper (Nienhaus \& Karatas, 2015), we explained in detail how some prior empirical studies attempting to establish differences between sukūk and conventional bonds (Ariff, Safari, \& Mohamed, 2013) had erred because of issues in the data set. The prior (and flawed) analysis was based on a comparison of yield to maturity (YTM) variances between conventional bonds and sukūk issued in Malaysia, ideally for the same maturity by the same issuer. Our conclusion is that the selection criteria for making meaningful pair-wise comparisons need to be better controlled, taking into account factors such as the obligor, the tenor, the duration (which incorporates the coupon rate that is paid out), the issuer's industry etc. (Nienhaus \& Karatas, 2015).

Moreover, we concluded that the earlier study (Ariff, Safari, \& Mohamed, 2013) focuses exclusively on securities within the Malaysian context, rendering a conclusion problematic for an increasingly globalized sukūk market. The authors link their observation to arguments from a study on stock market reactions after the announcement of sukūk or bond issuances by corporates. This is an inadequate reference, as their own observations are not related to corporates 
and their respective profit expectations: their observation refers predominantly to sukūk or bond issuances by Bank Negara Malaysia and the Government of Malaysia.

Another group of authors (Godlewski, Turk-Ariss, \& Weill, 2011, 2013, 2014) addressed a similar question - are sukūk and bonds different - from a different angle. They try to identify differences indirectly by observing the reaction of some variables such as stock prices on comparable "events" in the bond or sukūk markets. Different reactions on bond and sukūk market events would support the hypothesis that bonds and sukūk are different (or that sukūk are - at least in some respect - an asset class with distinct features). They found that stock markets react neutrally to the announcement of a conventional bond issue, but negatively to the announcement of a sukūk issue.

Their initial conclusions $(2011,2013)$ are very questionable insofar as the authors assume that sukūk are generally equity-like securities with profit-and-loss sharing (PLS) arrangements for the remuneration of the sukūk holders and the managing firm (typically the issuer). They explain the observed stock market reactions with an adverse selection problem inherent in PLS arrangements (Nienhaus \& Karatas, 2015).

Neither the general characterization of sukūk as equity-like securities nor the adverse selection explanation are convincing: The majority of sukūk are built on sales or leasing structures (murābahah, ijārah) which are not equity-like but debt-based with fixed payment obligations. This mistake has been corrected in their latest paper (Godlewski, Turk-Ariss, \& Weill, 2014) which produced more differentiated results. However, observed negative stock market reactions are again (mistakenly) explained by the adverse selection model (Nienhaus \& Karatas, 2015).

The aforementioned studies tried to provide empirical evidence that sukūk and bonds are not the same in economic terms. This evidence has not been provided. Sukūk and bonds do differ in their legal structures and, of course, in their Sharī'ah compliance. This implies a fundamental economic difference for Islamic investors for whom bonds do not have an economic value at all (because they are prohibited) and only sukūk are valuable papers. Thus, the question of whether sukūk and bonds are economically different is meaningful only with regard to market players who do have a choice and can invest in both types of securities. The studies reviewed do not differentiate between these two distinct groups of market actors (Nienhaus \& Karatas, 2015).

\subsection{Trading Practices}

Trading practices show, on the one hand, that conventional investment banks are, indeed, active in the sukūk market, which is mainly an OTC market. On the other hand, there are no strong indications that conventional players handle sukūk and bonds meaningfully differently on an operational level. A comparison of YTM may detect some statistical differences between sukūk and bonds, but there are many possible explanations. For example, both Islamic and conventional investors will participate in the initial offering of a new sukūk. An inelastic demand of Islamic investors may result in a higher issuing price (and respectively lower YTM) compared to a bond issue, ceteris paribus (Nienhaus $\&$ Karatas, 2015).

When Islamic investors tend to hold sukūk to maturity (for various reasons), the trading volumes and liquidity in the secondary market would be less than in the bond market, again with an impact on pricing and YTM, in the form of an illiquidity premium, etc. It is important to note that observable price or yield movements result from the overlapping market behavior of two groups of investors whose trading options and motives are different. Therefore, aggregate figures cannot prove (or disprove) that sukūk are, in economic terms, the same as bonds for only one of the two groups of the market participants, namely for the conventional players who are able to replace sukūk with bonds, or bonds with sukūk. In summary, more disaggregated data are needed (Nienhaus \& Karatas, 2015).

One economic difference between sukūk and bonds is obvious: Islamic financial institutions comprise a distinct group of market participants that are active in the sukūk markets but that do not operate in the conventional bond markets. However, the quantitative significance of this difference for the market processes and results is far from obvious. The relative size of the demand and supply of the different groups of actors will probably be a decisive factor, but it is difficult to measure because sukūk are mostly traded OTC, and official statistics rarely capture details of OTC transactions. Hence, it remains a challenge to integrate the models, data and practice of sukūk in a consistent way (Nienhaus \& Karatas, 2015).

Although we did not look into this in our study (Nienhaus \& Karatas, 2016), it would also be interesting to analyze whether a time-series study of the holding pattern in sukūk demonstrates any interesting patterns that deviate when compared to a static analysis of the holding patterns. For example, after a large general sell-off in the fixed income markets, does the proportion of conventional investors vis-à-vis Islamic investors in a given sukūk issuance increase or decrease at a greater rate? Anecdotally, it would appear that the proportion of conventional investors would decrease at a greater rate as they decrease their risk exposure in non-core holdings such as sukūk (Nienhaus \& Karatas, 2016).

\subsection{Interlinkages}


It is very hard to identify the major actors in the secondary markets, and it is particularly difficult to identify the volume of sukūk held and traded by conventional market players. Such information could shed some light on transmission channels and interlinkages both inside the Islamic banking sector and on interlinkages between the Islamic banking sectors and conventional finance. Interlinkages of various types actually attract much attention in the context of macroprudential surveillance, regulation and policy, which shall ensure the overall stability of the financial system (Nienhaus \& Karatas, 2016).

Information on holding patterns and trading volumes would be very useful to facilitate the analysis of transmission and contagion channels. These transmission channels are both between different sectors within the financial industry (e.g. banks, equity markets, fixed income markets - both within the Islamic and the conventional finance industry separately as well as between the conventional and Islamic industry) and between the financial industry and the real economy (Nienhaus \& Karatas, 2016).

While the holding pattern analysis was limited due to the paucity of the data set, nevertheless it confirmed that conventional investors are active in the sukūk markets, on the other hand Islamic financiers are in a clear preponderance. As conventional market players' role is primarily as intermediaries, their influence is not as significant as one might assume based on factors such as balance sheet size (Nienhaus \& Karatas, 2016).

Islamic financiers are primarily responsible for the spread of volatility from the broader conventional markets to sukūk based on the demonstrated parallelism of sukūk and bond yield curves. The implication is that developing the growth of the sukūk market would not shield emerging markets from the adverse impact of developed market interest rates (Nienhaus \& Karatas, 2016).

\section{Identification and Pair-wise Comparison of HQL Sukūk and Bonds}

It is worthwhile to briefly summarize our approach (method) for filling data gaps, and to spell out its limitations. This may encourage other researchers to come forward with other methods for reasonable estimations of secondary market activities of different market players and intra- and inter-sectoral linkages. It is vital to determine whether conventional financiers are substantial market actors, buying or selling sukūk in significant enough quantities to have a sway on sukūk pricing in the markets. The analysis of price movements in the secondary markets is practical only if there are sufficient trading volumes and a relatively high degree of sukūk liquidity (Nienhaus \& Karatas, 2016).

\subsection{Identification}

Larger sukūk and bond issuances are more liquid than smaller issuances because institutional investors are often only allowed to invest if there is a sizeable minimum outstanding volume of a paper i.e. USD 500 million and above. As the size of most private sector corporate sukūk issuances is often much lower than these benchmark size thresholds, conventional investors are biased towards large sovereign or government-backed sukūk. Our previous quantitative analysis concentrated on data for sovereign and quasi-sovereign sukūk that are highly liquid (Nienhaus \& Karatas, 2016).

Bloomberg data provided daily price and yield data. Bloomberg also provided information regarding holding patterns and when there were gaps in the dataset, this information was supplemented with proprietary data from a large Islamic financier. We limited the sukūk in our analysis to "large sovereign (or quasi-sovereign) USD denominated international sukūk." We had to determine appropriate pair-wise comparisons by finding sovereign-guaranteed conventional bonds with matching features in the order of priority listed underneath:

- The conventional bonds should be issued by the same sovereign obligor to control for any variances in idiosyncratic risk.

- The conventional bonds should be issued in the same currency denomination, namely USD in the case of international bonds.

- The conventional bond issuances should have similar amounts issued and outstanding.

- The conventional bond issuances should have the same credit ratings.

- The conventional bonds should have similar Modified Duration calculations or comparable maturities i.e. we compared a five-year maturity sukūk with a five-year maturity bond. Duration is commonly used to compare two asset classes in strategic asset allocation decision-making. (Note 5)

- The conventional bonds should have comparable coupon rates (captured in the Modified Duration calculation). (Note 5)

- The conventional bonds should be "Reg S" or 144A Series securities. (Note 4)

An inherent flaw in the study's methodology is that sukūk are by definition structured products that incorporate securitized transactions. Consequently, sukūk have a fundamentally different structural risk profile relative to 
plain-vanilla bonds. A conceptually more valid analysis would compare sukūk with conventional asset-based-securities (ABSs), especially covered bonds. The market reality is that there are no covered bonds, however, or other conventional ABSs issued by those sovereign obligors that are also frequent sukūk issuers. Covered bond or ABS issuers are typically banks or other non-sovereign obligors. Because of a lack of "matching" covered bonds, we used plain-vanilla conventional bonds for our analysis (Nienhaus \& Karatas, 2016).

\subsection{Market Behavior}

The analysis focuses on the behavior of the yield curves of the matched samples of respective sukūk and bonds. The analysis focused on whether the yield curves of matching sukūk and bonds run parallel and demonstrate the same spikes in reaction to external events with little or only marginal time differences. Bond and sukūk price data from Bloomberg was sourced using the following pricing hierarchy: 1) BGN or Bloomberg Generic Price, 2) EXCH or Exchange, and 3) TRACE. If the Bloomberg Generic Price is available, that is used. If the Bloomberg Generic Price is not obtainable, then the Exchange price is utilized, and finally if that is not obtainable either, then the TRACE price is used (Nienhaus \& Karatas, 2016).

More detailed information on the data can be found in our earlier paper (Nienhaus \& Karatas, 2016). We are also willing to share the full dataset with any aspiring researchers who would like to conduct analyses in detail, using methods that are more sophisticated than a univariate data analysis. If conventional investors perceive sukūk as assets that fall into the same asset class as conventional bonds then we would expect parallel yield curves for sukūk and "matching" bonds. We compare the yield curves of sukūk with the yield curves of "matching" bonds. "Matching" bonds are conventional bonds that share identical economic features with the sukūk such as the issuing entity, the geography, the currency, and the tenor (Nienhaus \& Karatas, 2016).

The availability of suitable pairs is limited. Some of the few available pairs are issuances that are more recent and so at the time of the analysis their yield data only covers approximately two-and-a-half years. If the analysis were conducted today, obviously there would be more data points to gather. Observations over longer periods and for a greater number of pairs would have allowed a better assessment of country-specific peculiarities and provided evidence that is more robust. However, at the time of the analysis, longer time series and pairs that are more appropriate were not obtainable. We attempted to quantify the relative weight of conventional and Islamic actors as sukūk yields are the product of trading activities of two distinct groups of actors. The available data on holding and trading patterns are insufficient for an elaborate quantitative analysis. As a result, we supplemented the available data with knowledge of market practices gained from market participants (Nienhaus \& Karatas, 2016).

\section{Market Processes}

Practitioners know that conventional financiers are a significant presence in the sukūk markets in the form of internationally operating banks and funds, as the sukūk markets provide them with a more diversified portfolio in terms of geography and obligors. Furthermore, it is often argued that Islamic sukūk investors generally tend to buy and hold sukūk to maturity because it could be difficult to replace sukūk that had been sold under favorable conditions with better Sharī'ah compliant fixed income securities. Issuances of new sukūk are still rather infrequent or irregular and of limited size while the secondary markets remain relatively shallow.

\subsection{Expected Tendencies}

Given the much wider choice of fixed income papers that can be used by conventional investors, they will not share the same reservations to sell sukūk if they see a good opportunity. If conventional investors only appreciate the financial (and not the Sharī'ah) qualities of a sukūk, they will compare sukūk with conventional bonds. This implies that they will identify much more "good opportunities" to sell sukūk because they have a much wider choice of securities for replacement. They do not have the restriction of Islamic investors to replace a sold sukūk with another (better) sukūk. So conventional market players who have bought sukūk from the primary markets may be more ready sellers in the secondary markets (Nienhaus \& Karatas, 2016).

This, however, must not be true for their role as buyers: if conventional investors are primarily interested in diversification in terms of geography and obligor, they could achieve this in nearly all cases by recourse to conventional bonds of the same issuers. Given the more limited universe of permissible securities, it could be assumed that the price elasticity of the sukūk demand of Islamic investors is less than that of conventional investors, meaning the demand of Islamic investors will drive sukūk prices somewhat higher (and yields lower) than the prices of comparable bonds. This would reduce the attractiveness of sukūk purchases in the secondary market for conventional market players, and over the lifetime of a sukūk, there should be a tendency to gradually reduce the holdings of each individual sukūk. The primary market is more attractive for a replenishment of sukūk portfolios as long as sovereign issuers price their new issuances in line with comparable bonds (Nienhaus \& Karatas, 2016). 


\subsection{Empirical Observations}

Figures 1, 2, 3, and 4 demonstrate the yield curve movements for sovereign Indonesia sukūk versus comparable sovereign Indonesia international bonds maturing in 2018, 2019, 2022 and 2024. The parallelism is apparent in the pair-wise yield curve comparisons. The yield curves of the local currency matching government bonds have also been included for illustration purposes (Nienhaus \& Karatas, 2016). Table 1 presents the standard deviations of the YTM data and the modified durations of each fixed income security. Table 2 presents the cross correlation comparing the USD-denominated Indonesia sovereign bonds with the USD-denominated matching sovereign sukūk. Our earlier analysis (Nienhaus \& Karatas, 2016) covers other countries as well, namely, Turkey, Malaysia, and Hong Kong, but we only include the Indonesia findings in this paper for purposes of brevity.

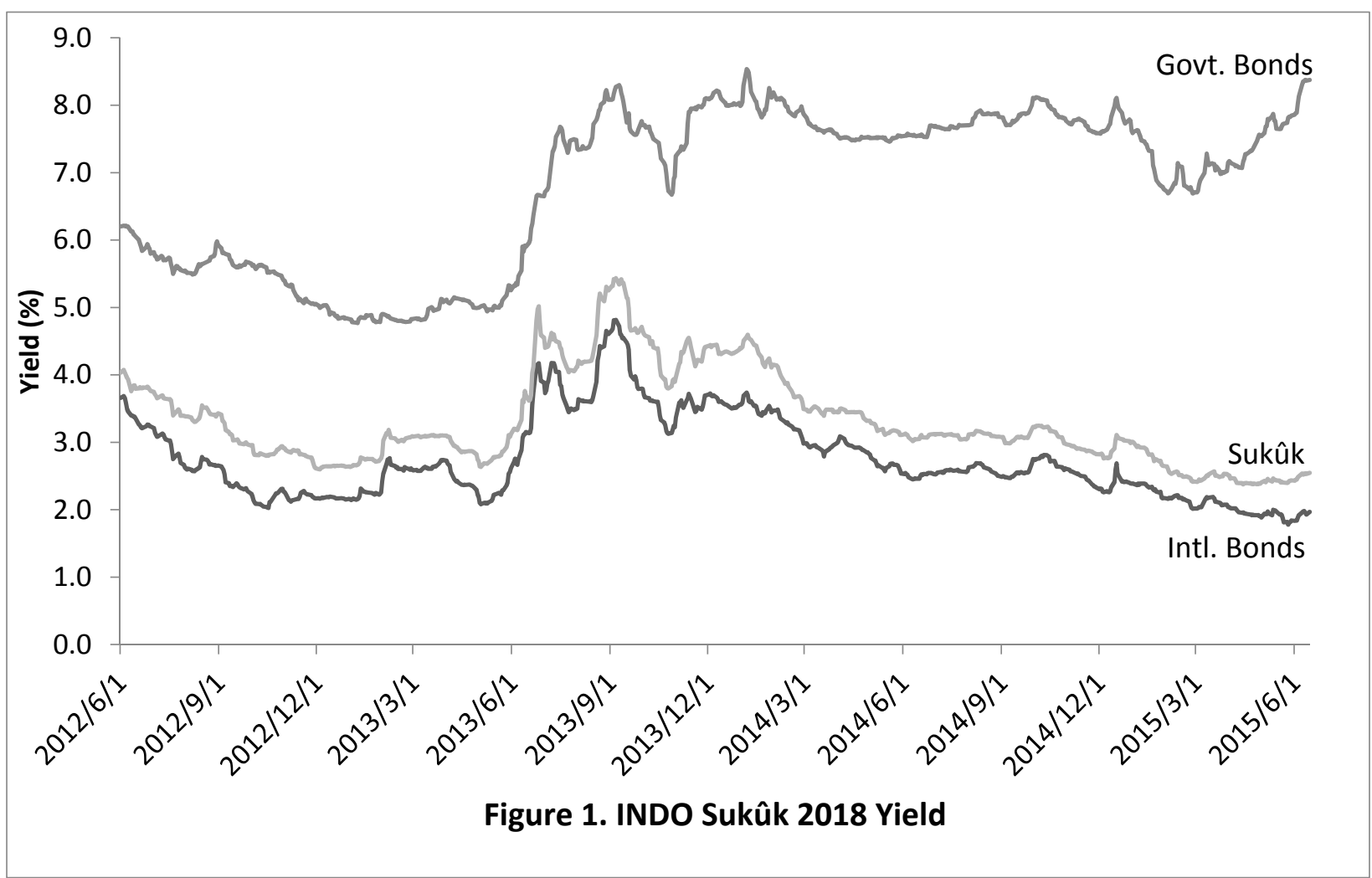



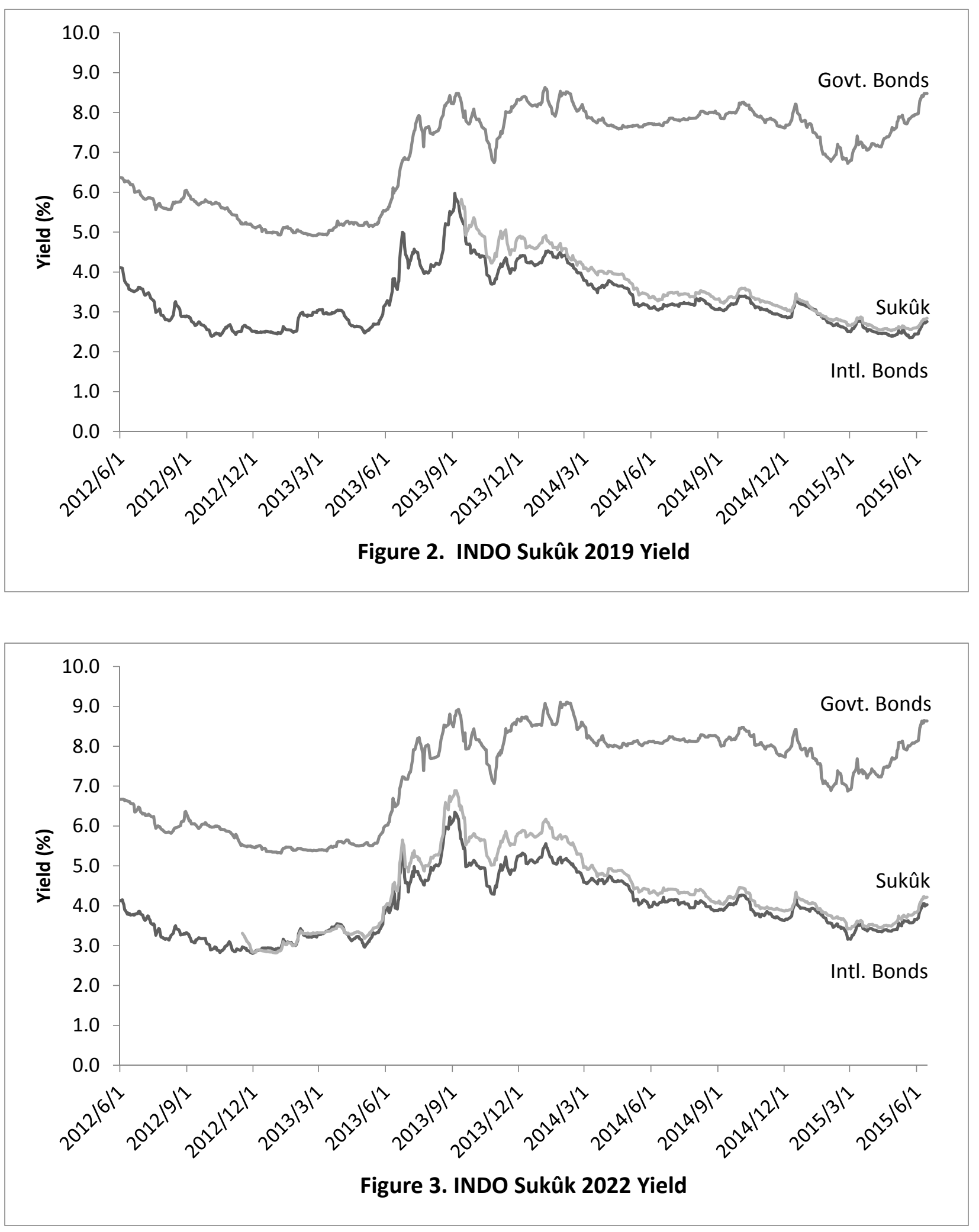


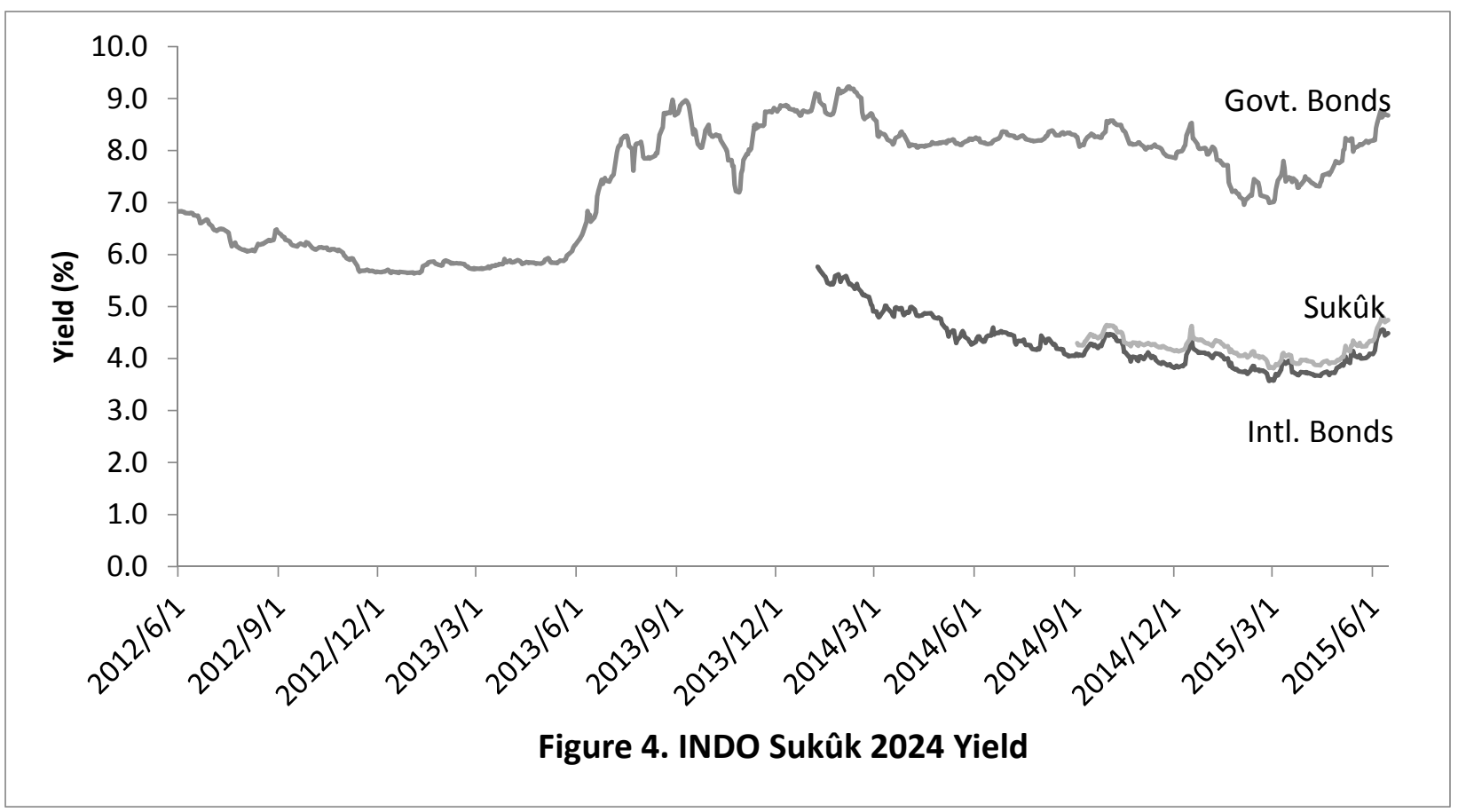

Data: Bloomberg

Table 1. Indonesia Sukūk 2018, 2019, 2022 and 2024

\begin{tabular}{ccccccccc}
\hline & \multicolumn{2}{c}{$\mathbf{2 0 1 8}$} & \multicolumn{2}{c}{$\mathbf{2 0 1 9}$} & \multicolumn{2}{c}{$\mathbf{2 0 2 2}$} & \multicolumn{2}{c}{$\mathbf{2 0 2 4}$} \\
\cline { 2 - 9 } & SD & MD & SD & MD & SD & MD & SD & MD \\
\hline USD Intl. Bond & $1.583 \%$ & 2.282 & $1.700 \%$ & 3.033 & $1.664 \%$ & 5.898 & $1.226 \%$ & 6.610 \\
USD Sukūk & $1.380 \%$ & 3.135 & $1.324 \%$ & 3.276 & $1.401 \%$ & 6.409 & $1.051 \%$ & 7.366 \\
IDR Govt. Bond & $0.845 \%$ & 2.513 & $0.878 \%$ & 3.252 & $0.979 \%$ & 4.855 & $0.936 \%$ & 5.969 \\
\hline
\end{tabular}

$\mathrm{SD}=$ Standard Deviation, $\mathrm{MD}=$ Modified Duration

Table 2: Cross Correlation between Indonesia USD International bonds and USD Sukūk

\begin{tabular}{lrrrr} 
Indonesia & $\mathbf{2 0 1 8}$ & $\mathbf{2 0 1 9}$ & $\mathbf{2 0 2 2}$ & \multicolumn{2}{c}{$\mathbf{2 0 2 4}$} \\
\cline { 2 - 5 } & 0.789 & 0.825 & 0.90 & 0.92 \\
\hline
\end{tabular}

Although at best anecdotal evidence can be presented for the trading activities of conventional market players in secondary sukūk markets, a trading pattern can be deduced that is matched (or at least is not nullified) by observable yield curves: conventional market players can react on developments in conventional markets by offering sukūk, and by buying sukūk from conventional parties the Islamic investors "import" conventional market movements into the Islamic finance system. This explains the parallel movement of sukūk and bond yield curves for internationally traded liquid sukūk (Nienhaus \& Karatas, 2016).

The yield curve parallelism reflects the dependency of financial variables such as prices, costs of financing etc. in the Islamic segment on developments in the broader conventional segment of the markets. If we assume that conventional actors are not determinative in sukūk price formation, the observed parallelism suggests that Islamic investors are responsible for the spread of volatility from the conventional markets to sukūk. Islamic financiers would seem to react in a similar fashion to the same trigger events as conventional market investors (Naifar \& Hammoudeh, 2016). An expansion of the size of the sukūk market would not allow emerging markets to shield themselves against the adverse impact of developed market interest rates (Nienhaus \& Karatas, 2016).

\subsection{LAB Portfolio Construction}

In another earlier paper (Karatas, 2016) we tested the hypothesis of whether a sukūk LAB portfolio could be structured for a megabank MDB. The conclusion of the analysis was that a newly established MDB would be able to structure an appropriate LAB portfolio without "crowding out" other investors from the sukūk market. The constraints in the analysis were the size and structure of the sukūk market in 2015 as well as the requirements of the credit rating agencies' 
methodologies that an MDB would have to satisfy (Karatas, 2016).

We also deliberated on how the markets might respond to the structuring of this portfolio by a new MDB. Will the MDB's additional demand lead to its own additional supply? Will there be a crowding-out effect because the MDB absorbs a major share of available HQL sukūk? (Karatas, 2016). The contribution of this paper to the extant literature is significant as it empirically demonstrates that the breadth and the depth of the sukūk market in its current form can accommodate a new MDB that only uses sukūk for its HQLA portfolio. Simultaneously, the findings of the paper also empirically highlight the limitations of the sukūk market, as the formation of an HQL sukūk portfolio for an MDB is sensitive to several factors such as maturity and credit rating constraints, and remains vulnerable to the effect of sovereign credit rating downgrades.

The study was limited to sukūk and bond securities denominated in SDR basket currencies. The reporting currency of most MDBs are USD or SDR and their liquidity policies typically only allow investments denominated in SDR or other hard currencies (Karatas, 2016). The methodology is rather straightforward: we started with a large universe of sukūk. Then several layers of filters are defined to reflect the requirements of an MDB and applied successively to the sukūk universe. Beginning with the universe of SDR denominated sukūk and applying a filter for maturity limits, the number of sukūk issuances and the amount of sukūk outstanding decreased considerably. In the end, after passing all filters, a sufficient number of sukūk are left so that a portfolio is compiled (Karatas, 2016).

The analysis provides empirical weight to the megabank discussions by demonstrating that a LAB portfolio of HQL sukūk can be constructed. There are limits considering the smaller outstanding size of the sukūk market compared to the conventional bond market. The most restrictive filters that allow or prevent the portfolio construction are the credit rating and the maximum maturity requirements. The critical threshold levels for the value of these parameters are BBBfor the credit rating and a ten-year maturity limit for the maximum tenor limit. These parameters are critical considering the high concentration of BBB- rated sovereign sukūk issuances and considering the relatively high concentration of ten-year maturity sovereign sukūk issuances. These two critical thresholds overlap, as there was "a relatively high concentration of ten-year maturity BBB- sovereign sukūk issuances" (Karatas, 2016).

After finalizing the analysis, we conclude that a greenfield MDB with a USD 20 billion balance sheet can achieve a USD 5 billion HQL sukūk liquidity portfolio. The USD 5 billion portfolio would also generate a weighted average coupon return of 3.86\%, higher than the benchmark Dow Jones Sukuk Investment Grade Index comparable return of $3.44 \%$ as of December 2015 per Bloomberg (Karatas, 2016).

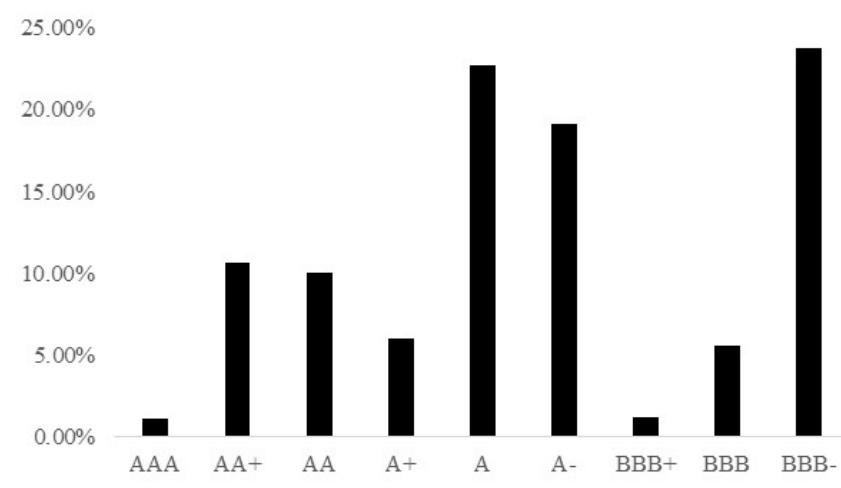

Figure 5. LAB Sukūk Portfolio by Rating 


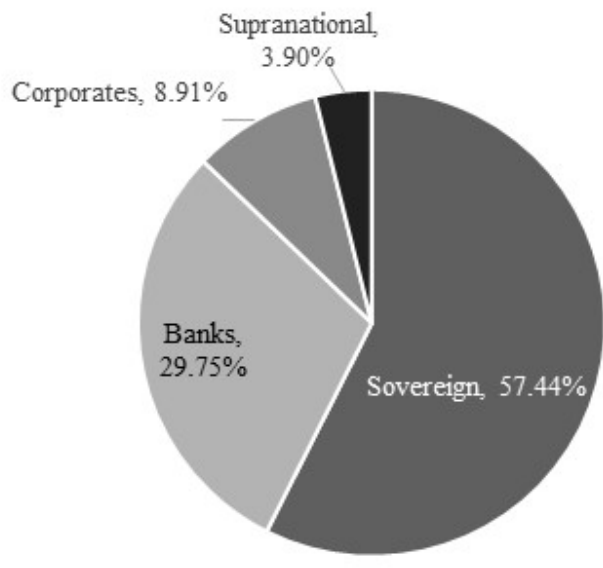

Figure 6. LAB Sukūk Portfolio by Obligor Type

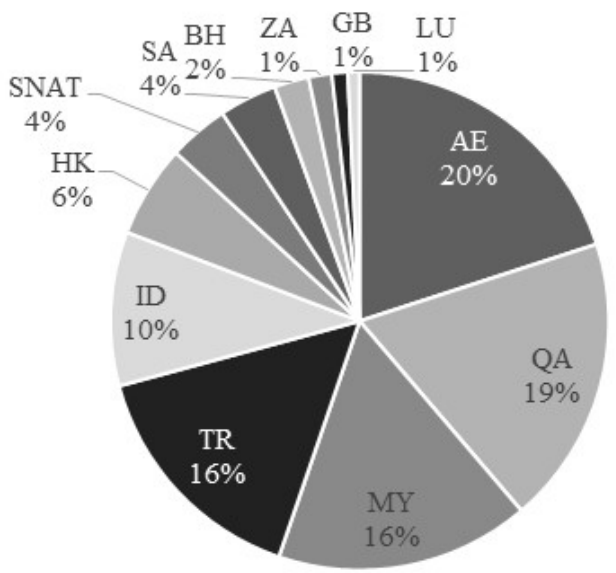

Figure 7. LAB Sukūk Portfolio by Obligor Country

Data: Bloomberg data as of February 1, 2016

The credit rating profile indicates a diversified portfolio from a credit quality perspective per Figure 5 . There is a "bar-belled" distribution in the credit rating profile, however, with a concentration in the BBB- and the A / A- rating buckets. As shown in Figure 6, more than half of the sukūk in the LAB portfolio is sovereign in nature, while almost a third of the sukūk are Bank issuances. The country exposure of the portfolio is concentrated in five countries, comprising roughly $80 \%$ of the sukūk per Figure 7 (Karatas, 2016).

\section{Thoughts on the Future of the HQL Sukūk Markets}

All of our findings indicate various possible scenarios for the future of the sukūk markets in general and for HQL sukūk in particular. The scenarios also have to consider the possible impacts of a prolonged period of relatively low oil prices and of rising interest rates in advanced economies, particularly in the U.S. Given the data limitations spelled out before, it should be fair enough not to expect an elaborate quantitative forecast but just some "intelligent guesses."

We have already witnessed corporate bond issuances slowing down significantly since the November 2016 U.S. election as borrowing costs have increased sharply. Bond yields rose aggressively as the market assumed a more balanced inflation outlook and a more rapid normalization of interest rates by the U.S. Fed. The consensus in the market is that interest rates are likely to rise a lot faster than previously thought under President Trump. The recent sell-off in bonds reflects the fear that inflation will rise, forcing central banks to raise interest rates faster than the market had previously been pricing for 2017 and onwards. 
This slowdown in overall bond issuances has also affected the sukūk markets, with sukūk issuance volumes significantly lower in Q3 and Q4 2016 compared to previous years. This slowdown in sukūk activity is in line with the findings of our various empirical analyses and empirical literature reviews, which demonstrated strong interlinkages between the sukūk markets and comparable conventional bonds as demonstrated through yield curve parallelism. Demand for sukūk has declined due to tighter liquidity conditions across the GCC region and expectations of rising interest rates and the supply of new sukūk has slowed down to a trickle as issuers take pause to gauge the markets.

In addition to interest rates, another constraint to the supply of new sukūk is that lower oil and natural gas prices could reduce the liquidity of GCC-based Sharī ah compliant banks. GCC-based Sharī'ah compliant banks have comprised a large proportion of the demand equation for sukūk in the past, and so, any decrease in their demand for sukūk could lead to diminished new supply. Lower oil prices may also spur more sovereign sukūk issuances by GCC countries, however, which would help to deepen the sukūk markets. Nevertheless, it is important to bear in mind that Saudi Arabia, which issued USD 17.5 billion of sovereign bonds in a jumbo-sized conventional bond issuance in October, 2016, and Qatar, which issued USD 9 billion of sovereign bonds in May, 2016, both did not issue sovereign sukūk.

The decision to issue conventional bonds as opposed to sukūk was likely due to tightening liquidity conditions in the GCC and, more importantly, the ability to reach a much wider and diversified investor audience with a conventional bond issuance, which would have resulted in a commensurately lower issuance cost and tighter pricing. The rationale of whether to issue a conventional bond versus a sukūk issuance, based on market receptivity and realities, contradicts much of the prevailing academic writings on who issues sukūk and when (Nagano, 2016). There is a chance that a sovereign sukūk issuance from the GCC may come to the market later, but probably in a more symbolic size. One other limitation on the supply side is that with each new sukūk, there may be a reduction in the availability of unencumbered assets to the obligor, which has led to some sukūk issuers issuing only once.

As liquidity dries up globally with the U.S. Fed raising interest rates, and natural resource generated income declines for Malaysia and the GCC, sukūk yields should increase commensurately. This increase in sukūk yields could potentially render sukūk more attractive as eligible investments for a greater number of conventional investors; if this effect is large enough, the aggregate demand for sukūk may not shrink substantially, and could potentially even increase. Based on evidence from the markets, however, there has been a decline in the overall demand for sukūk in both Q3 and Q4 2016, largely in anticipation of rising interest rates.

There was a rash of sovereign credit rating downgrades of some GCC countries by the credit rating agencies in February 2016 because of declining oil prices. Any further sovereign credit rating downgrades would complicate LAB portfolio construction for an MDB. This complication would be exacerbated if the downgrades were to impact sukūk issuers rated BBB- as sub investment-grade rated sukūk would not be eligible for a LAB portfolio (Karatas, 2016).

Given the smaller size of the sukūk market relative to the conventional bond market, and the difficulty in sourcing HQL sukūk to construct a LAB portfolio, constructing such a LAB portfolio would become much more difficult if frequent sukūk issuers had their credit ratings downgraded. Additionally, the task of sourcing HQL sukūk for a LAB portfolio would become more difficult if maximum tenor limits were constricted by more stringent rating agency methodologies for MDBs, which might entail higher haircuts for longer maturity sukūk (Karatas, 2016).

Aside from the market for U.S. Treasury bonds, one could argue that liquidity is an issue confounding conventional bonds as well, and not only the sukūk market. The significantly smaller size of the sukūk market means that an MDB would have less room to maneuver, however, if the decisive parameters for a sukūk LAB portfolio were to come under increased pressure (Karatas, 2016). Going forward, the outlook for HQL sukūk will likely be tested aggressively by the markets as global interest rates rise, further compounding existing limitations concerning the availability and the liquidity of HQL sukūk. Based on the empirical findings discussed in this paper, the solution to the constraints on HQL sukūk and LAB portfolio construction could be for regulatory and sovereign bodies to encourage more highly rated sukūk issuances with short-term maturities to help the Islamic banking industry weather the rising global interest-rate environment.

\section{References}

Ariff, M., \& Safari, M. (2012). Are Sukuk Securities the Same as Conventional Bonds? AfroEurasian Studies 1(1), 101 -125. Available at: http://afroeurasianstudies.net/dosyalar/site_resim/veri/1839572.pdf

Ariff, M., Safari, M., \& Mohamed, S. (2013). Sukuk Securities and Conventional Bonds: Evidence of Significant Differences. Pertanika Journal of Social Sciences and Humanities 21(2), 621-638. Available at: http://www.pertanika.upm.edu.my/Pertanika\%20PAPERS/JSSH\%20Vol.\%2021\%20(2)\%20Jun.\%202013/15\%20P age\%20621-638.pdf

Ibrahim, M. H. (2015). Issues in Islamic banking and finance: Islamic banks, Shari'ah-compliant investment and sukuk. Pacific-Basin Finance Journal, 34, 185-191. http://dx.doi.org/10.1016/j.pacfin.2015.06.002 
IFSB (2016). Islamic Financial Services Industry Stability Report 2016. IFSB, Kuala Lumpur. Available at: http://www.ifsb.org/docs/IFSI\%20Stability\%20Report\%202016\%20(final).pdf

Godlewski, C. J., Turk, R., \& Weill, L. (2014). Do the Type of Sukuk and Choice of Shari'a Scholar Matter? IMF Working Paper 14/147. Washington: IMF. Available at: https://www.imf.org/external/pubs/ft/wp/2014/wp14147.pdf

Godlewski, C. J., Turk-Ariss, R., \& Weill, L. (2011). Do Markets Perceive Sukuk and Conventional Bonds as Different Financing Instruments? BOFIT Discussion Papers 6/2011. Helsinki: Bank of Finland. Available at: http://www.suomenpankki.fi/bofit/tutkimus/tutkimusjulkaisut/dp/documents/dp0611.pdf

Godlewski, C. J., Turk-Ariss, R., \& Weill, L. (2013). Sukuk vs. Conventional Bonds: A Stock Market Perspective. Journal of Comparative Economics, 41(3), 745-761. http://dx.doi.org/10.1016/j.jce.2013.02.006

Karatas, A. (2016). Sukūk Market Depth and Breadth Analysis: LAB (Liquid Assets Buffer) Portfolio Construction for a Non-Depository Megabank MDB. Applied Economics and Finance, North America, 3(4), 78-94. http://redfame.com/journal/index.php/aef/article/view/1670/1797

Maghyereh, A., \& Awartani, B. (2016). Dynamic transmissions between Sukuk and bond markets. Research in International Business and Finance, 38, 246-261. http://dx.doi.org/10.1016/j.ribaf.2016.04.016

Nagano, M. (2016). Who issues Sukuk and when?: An analysis of the determinants of Islamic bond issuance. Review of Financial Economics. Available at: http://dx.doi.org/10.1016/j.rfe.2016.05.002

Naifar, N., \& Mseddi, S. (2013). Sukuk spreads determinants and pricing model methodology. Afro-Asian Journal of Finance and Accounting, 3(3). http://dx.doi.org/10.1504/AAJFA.2013.054425

Naifar, N. \& Hammoudeh, S. (2016). Do global financial distress and uncertainties impact GCC and global sukuk return dynamics? Pacific-Basin Finance Journal, 39, 57-69. http://dx.doi.org/10.1016/j.pacfin.2016.05.016

Nienhaus, V. \& Karatas, A. (2016). Market perceptions of liquid sovereign Sukūk: A new asset class? International Journal of Islamic and Middle Eastern Finance and Management, 9(1), 87-108. http://dx.doi.org/10.1108/IMEFM-03-2015-0027

Nienhaus, V., \& Karatas, A. (2015). Comparing Sukūk and Conventional Securities: The Challenge of Consistency. Journal of Islamic Banking and Finance, 3(2), 15-23. http://dx.doi.org/10.15640/jibf.v3n2a2

Wigglesworth, R., \& Moore, E. (2016, December 1). Bond rout intensifies as oil surges. Financial Times. https://www.ft.com/content/e97e3778-b7de-11e6-961e-a1acd97f622d

Zulkhibri, M. (2015). A synthesis of theoretical and empirical research on sukuk. Borsa Istanbul Review, 15(4), 237-248. http://dx.doi.org/10.1016/j.bir.2015.10.001 


\section{Notes}

Note 1. A sukūk is a financial contract that shares similar characteristics to a conventional bond with the key difference being that sukūk are either asset backed or asset based. Sukūk represent proportionate beneficial ownership in the underlying tangible asset(s) of particular projects or investment activities. In terms of structure, a sukūk is similar to a covered bond.

Note 2. A term used in Islamic finance to denote that a financial product or activity complies with the requirements of Shari ${ }^{`}$ ah, or Islamic law. Risk sharing is one of the quintessential features of Islamic financing and the key defining characteristics in the application of Shari ${ }^{\top}$ ah to financing structures are that transactions should be based on tangible assets, and should not bear interest.

Note 3. Commodity murābahah placements are very similar in function to short-term money-market placements in conventional finance. A murābahah contract is essentially cost-plus financing: a contract sale between a bank and a counterparty for the sale of goods at a price that includes a profit margin pre-agreed by both parties. A commodity murābahah placement is a murābahah contract using certain specified commodities, typically through a metals exchange such as the London Metal Exchange.

Note 4. We identify sukūk holders as buyers of "144A" or "Reg S" securities as indicated in the Bloomberg database for the registered market players. Securities under rule 144A are bonds or sukūk that are sold in the U.S. to U.S. domiciled investors. With a few small possible exceptions, all these buyers are conventional investors. Regulation S or "Reg S" securities are bonds or sukūk that are issued in the Eurobond market for international investors. These (non-U.S.) international buyers can be either conventional or Islamic investors.

Note 5.

$$
\operatorname{ModD}(y) \equiv-\frac{1}{V} \cdot \frac{\partial V}{\partial y}=-\frac{\partial \ln (V)}{\partial y}
$$

\section{Copyrights}

Copyright for this article is retained by the author(s), with first publication rights granted to the journal.

This is an open-access article distributed under the terms and conditions of the Creative Commons Attribution license which permits unrestricted use, distribution, and reproduction in any medium, provided the original work is properly cited. 